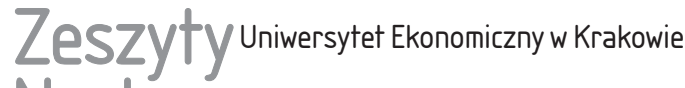 Naukowe
}

\section{Współpraca przedsiębiorstw w zakresie działalności innowacyjnej na przykładzie sektora usług}

\section{Streszczenie}

Celem opracowania jest zidentyfikowanie różnic dotyczących współpracy przedsiębiorstw w zakresie działalności innowacyjnej w Unii Europejskiej. Wyjaśniono w nim pojęcie działalności innowacyjnej przedsiębiorstw oraz scharakteryzowano współpracę w zakresie działalności innowacyjnej przedsiębiorstw z sektora usług według wybranych grup instytucji partnerskich.

Przedsiębiorstwa z sektora usług w krajach zaliczanych do liderów innowacyjności w znacznie większym stopniu współpracują w zakresie działalności innowacyjnej z instytucjami partnerskimi niż w krajach o niskiej czy umiarkowanej innowacyjności. Szczególnie ważna dla innowacyjności gospodarki jest współpraca przedsiębiorstw z sektora usług z dostawcami sprzętu (Dania, Holandia), z klientami z sektora prywatnego (Finlandia, Szwecja) oraz ze szkołami wyższymi (Niemcy).

Słowa kluczowe: sektor usług, działalność innowacyjna, współpraca przedsiębiorstw, innowacja.

Klasyfikacja JEL: O3, O31.

Grażyna Węgrzyn, Uniwersytet Ekonomiczny we Wrocławiu, Wydział Ekonomii, Zarządzania i Turystyki w Jeleniej Górze, Katedra Ekonomii i Polityki Ekonomicznej, ul. Nowowiejska 3, 58-500 Jelenia Góra, e-mail: grazyna.wegrzyn@ue.wroc.pl 


\section{Wprowadzenie}

Współczesne gospodarki, określane mianem gospodarek opartych na wiedzy, rozwijają się w głównej mierze dzięki wykorzystywaniu wiedzy i innowacji. Działalność innowacyjna przedsiębiorstw odgrywa niekwestionowaną rolę w budowaniu przewagi konkurencyjnej zarówno samych przedsiębiorstw, regionów, jak i gospodarek. Wdrażane innowacje umożliwiają firmom zwiększanie zysków, dynamiczny rozwój oraz poprawę pozycji na rynku. W procesie tworzenia i wdrażania innowacji szczególnego znaczenia nabiera współpraca w zakresie działalności innowacyjnej. Współpraca z innymi podmiotami stanowi bardzo ważny element działalności każdego przedsiębiorstwa. Umożliwia szerszy dostęp do wiedzy i nowych technologii oraz często stanowi warunek skutecznego wdrożenia innowacji.

Coraz częściej naukowcy zajmujący się innowacjami skupiają swą uwagę na sektorze usług, który do niedawna był uważany za mało podatny na innowacje [Ietto-Gillies 2002, s. 37]. Sektor usług zaczyna dominować zarówno w wytwarzaniu PKB, jak i w zatrudnianiu pracowników. Pomiędzy sektorem usług a gospodarką zachodzą interakcje. $Z$ jednej strony rozwój sektora usług zależy od poziomu rozwoju społeczno-gospodarczego, a z drugiej poziom rozwoju gospodarki jest determinowany właśnie przez rozwój usług, a zwłaszcza usług opartych na zaawansowanej wiedzy [Węgrzyn 2015, s. 31-32]. Firmy z sektora usług wykazują coraz większe zainteresowanie prowadzeniem działalności innowacyjnej, szczególnie w zakresie innowacji organizacyjnych i marketingowych. Z doświadczeń wielu przedsiębiorstw wynika, że firmy współpracujące w obszarze innowacyjności więcej inwestują w potencjał innowacyjny i osiągają lepsze rezultaty niż firmy nieangażujące się w taką współpracę [Popławski 2009, s. 214].

Celem opracowania jest zidentyfikowanie różnic dotyczących współpracy przedsiębiorstw w zakresie działalności innowacyjnej w Unii Europejskiej. Na potrzeby prowadzonych rozważań sformułowano hipotezę główną: innowacyjność gospodarki jest determinowana przez współpracę przedsiębiorstw w zakresie działalności innowacyjnej. Dane wykorzystywane w opracowaniu pochodzą ze sprawozdań o innowacjach w sektorze usług (Community Innovation Survey 2012 - CIS 2012) i obejmują lata 2010-2012․ Sektor usług w badaniu CIS 2012 obejmuje następujące sekcje PKD: sekcję $\mathrm{G}$ - handel hurtowy i detaliczny, naprawa pojazdów samochodowych, włączając motocykle; sekcję $\mathrm{H}$ - transport i gospodarka magazynowa; sekcję $\mathrm{J}$ - informacja i komunikacja; sekcję $\mathrm{K}$ - działalność

${ }^{1}$ Dane z kolejnego badania CIS 2014, obejmujące lata 2012-2014, nie były jeszcze dostępne w bazie Eurostatu w momencie przygotowywania artykułu do publikacji. 
finansowa i ubezpieczeniowa; sekcję M - działalność profesjonalna, naukowa i techniczna.

Opracowanie składa się z dwóch części. W części pierwszej wyjaśniono pojęcie działalności innowacyjnej przedsiębiorstw oraz przedstawiono udział przedsiębiorstw z sektora usług aktywnych innowacyjnie w liczbie przedsiębiorstw ogółem w poszczególnych państwach Unii Europejskiej. W części drugiej scharakteryzowano współpracę w zakresie działalności innowacyjnej przedsiębiorstw z sektora usług ze szczególnym uwzględnieniem wybranych grup instytucji partnerskich. Opracowanie kończą wnioski z przeprowadzonej analizy.

\section{Działalność innowacyjna przedsiębiorstw z sektora usług}

Działalność innowacyjna przedsiębiorstw jest pojęciem bardzo szerokim i odnosi się do działań o charakterze naukowym, technicznym, finansowym, organizacyjnym i komercyjnym, które prowadzą lub mają w zamierzeniu prowadzić do wdrażania innowacji. Niektóre z tych działań mają charakter innowacyjny, z kolei inne nie są nowością, lecz są konieczne do wdrażania innowacji [Neć 2013, s. 114]. Działalność innowacyjna obejmuje także działalność badawczo-rozwojową (B+R), która nie jest bezpośrednio związana z tworzeniem konkretnej innowacji [Działalność innowacyjna... 2012, s. 13]. W metodologii stosowanej przez GUS i Eurostat działalność innowacyjna dotycząca produktów lub procesów może oznaczać zarówno działalność innowacyjną aktualnie prowadzoną, jak i działalność innowacyjną zaniechaną. Z kolei gdy dotyczy działalności nie technologicznej, tj. marketingowej lub organizacyjnej, zawsze odnosi się do działalności zakończonej, co oznacza, że nowa bądź ulepszona metoda marketingowa została zastosowana, a zmiana organizacyjna wdrożona. Ponadto wyróżnia się przedsiębiorstwa aktywne innowacyjnie oraz przedsiębiorstwa innowacyjne, z podziałem na przedsiębiorstwa przemysłowe i przedsiębiorstwa z sektora usług. Przedsiębiorstwo aktywne innowacyjnie to takie, które w badanym okresie wprowadziło przynajmniej jedną innowację produktową lub procesową lub realizowało w tym okresie przynajmniej jeden projekt innowacyjny, który został przerwany lub zaniechany w trakcie badanego okresu lub nie został do końca tego okresu ukończony. Natomiast przedsiębiorstwo innowacyjne to takie, które w badanym okresie wprowadziło na rynek przynajmniej jedną innowację produktową lub procesową [Działalność innowacyjna... 2012, s. 29].

W latach 2010-2012 w Unii Europejskiej (UE-28) przedsiębiorstwa aktywne innowacyjnie stanowiły 48,9\% ogółu przedsiębiorstw (rys. 1). Udział innowacyjnych przedsiębiorstw przemysłowych i usługowych w ogólnej liczbie przedsiębiorstw wyniósł odpowiednio 51,0\% i 46,8\%. W poszczególnych państwach Unii Europejskiej sytuacja pod tym względem była zróżnicowana. Największym 
odsetkiem aktywnych innowacyjnie przedsiębiorstw przemysłowych charakteryzowały się Niemcy $(70,3 \%)$, Luksemburg $(66,5 \%)$ i Irlandia $(66,2 \%)$, natomiast w sektorze usług - Luksemburg $(66,0 \%)$, Niemcy $(63,5 \%)$ i Portugalia $(61,6 \%)$. Najniższy odsetek aktywnych innowacyjnie przedsiębiorstw przemysłowych wystąpił w Rumunii (18,7\%), Polsce (22,5\%) i Bułgarii (23,2\%), a w sektorze usług odpowiednio w Rumunii $(22,5 \%)$, Polsce $(23,4 \%)$ i na Łotwie $(29,3 \%)$.

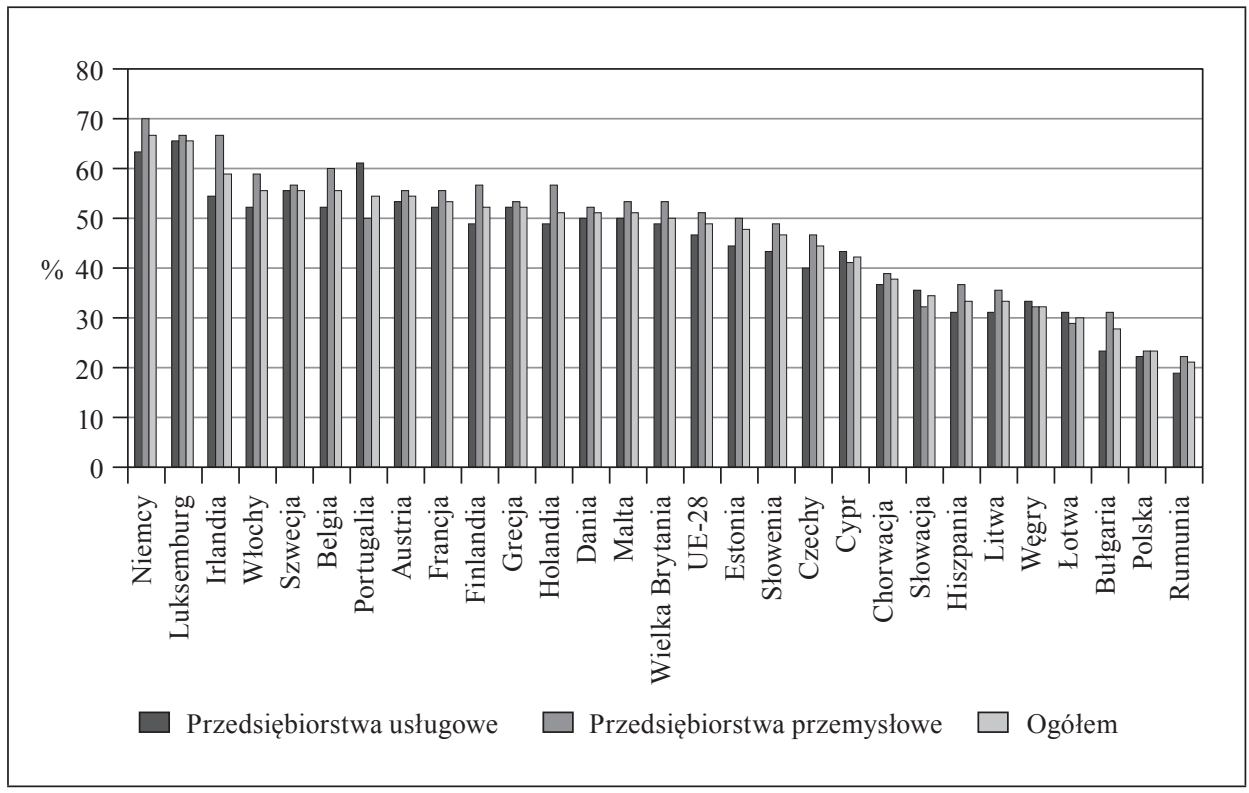

Rys. 1. Udział przedsiębiorstw aktywnych innowacyjnie w ogólnej liczbie przedsiębiorstw w Unii Europejskiej w latach 2010-2012

Źródło: http://appsso.eurostat.ec.europa.eu/nui/show.do?dataset=inn_cis8_type\&lang=en (data dostępu: 9.08.2016).

Z przeprowadzonej analizy wynika, że polskie przedsiębiorstwa zarówno przemysłowe, jak i usługowe są mało aktywne innowacyjnie. Wprowadzają mniej innowacji niż chociażby firmy z tzw. nowych państw Unii Europejskiej, co przekłada się na niski poziom innowacyjności całej gospodarki.

Według najnowszego raportu Innovation Union Scoreboard 2016 [2016, s. 8 i 96] syntetyczny wskaźnik innowacyjności (summary innovation index - SII) dla Polski kształtował się na poziomie 0,292. Polska znalazła się wśród krajów o umiarkowanej innowacyjności (moderate innovators), wyprzedzając jedynie Rumunię $(0,180)$, Bułgarię $(0,242)$, Łotwę $(0,281)$ i Litwę $(0,282)$. Liderami innowacyjności (innovation leaders) są: Szwecja $(0,704)$, Dania $(0,700)$, Finlandia $(0,649)$, Niemcy $(0,632)$ i Holandia $(0,631)$. 


\section{Współpraca w zakresie działalności innowacyjnej}

Współpraca z innymi podmiotami w zakresie działalności innowacyjnej odgrywa ważną rolę w funkcjonowaniu każdego przedsiębiorstwa. Dzięki tej współpracy przedsiębiorstwo uzyskuje dostęp do wiedzy i nowych technologii, a to przekłada się na obniżenie kosztów i ryzyka prowadzonej działalności gospodarczej, a także sprzyja wymianie doświadczeń i wiedzy. Według M.E. Portera [1990] niewiele firm jest w stanie prowadzić swoją działalność innowacyjną w izolacji, a otoczenie przedsiębiorstw odgrywa kluczową rolę w uwalnianiu potencjału przedsiębiorstw. Przedsiębiorstwa mogą pozyskiwać wiedzę na temat innowacji z różnych źródeł, partnerstwo, alianse i joint ventures z podmiotami zewnętrznymi lub przez nabywanie wiedzy przez zakup licencji czy umowy na prowadzenie prac B+R [Działalność innowacyjna... 2015, s. 10].

Według GUS i Eurostatu współpraca w zakresie działalności innowacyjnej oznacza czynny udział we wspólnych projektach z innymi przedsiębiorstwami lub instytucjami niekomercyjnymi. Taka współpraca może mieć charakter perspektywiczny i długofalowy i nie musi pociągać za sobą bezpośrednich, wymiernych korzyści ekonomicznych dla biorących w niej udział partnerów [Działalność innowacyjna... 2015, s. 97]. Warto podkreślić, że według przyjętej metodologii za współpracę w zakresie działalności innowacyjnej nie uznaje się zamawiania prac u wykonawców zewnętrznych, jeżeli przedsiębiorstwo nie bierze aktywnego udziału w ich realizacji.

Współpraca przedsiębiorstw w zakresie działalności innowacyjnej jest stosunkowo nową formą współpracy, ale obserwuje się systematyczny wzrost zainteresowania właśnie tą formą. Do głównych korzyści osiąganych z tytułu współpracy w zakresie działalności innowacyjnej można zaliczyć [Popławski 2009, s. 215; Szymoniuk i Walkiewicz 2001, s. 105-206; Cygler 2013, s. 21]:

- unikanie powielania działalności B+R dotyczącej tego samego/podobnego produktu czy usługi,

- współfinansowanie działalności innowacyjnej, a w konsekwencji obniżenie kosztów tej działalności,

- skrócenie czasu realizacji przedsięwzięcia,

- przyspieszenie pozyskiwania deficytowych zasobów (szczególnie niematerialnych), które stają się źródłem przewagi konkurencyjnej,

- upowszechnienie postępu technicznego i technologicznego,

- zwiększenie poziomu innowacyjności zarówno przedsiębiorstwa, jak i całej gospodarki,

- zwiększanie starań o środki pomocowe z funduszy krajowych i zagranicznych.

Czynnikiem ograniczającym możliwość i zakres współpracy są niewątpliwie koszty transakcyjne, związane z koniecznością koordynacji, zarządzania i moni- 
torowania działalności innowacyjnej kilku stron współpracy [Popławski 2009, s. 215]. Ponadto współpraca może być narażona na zagrożenia w postaci nieprzewidzianego ryzyka, np. przekraczania ustalonych terminów, niepowodzenia działalności B+R czy zmiany sytuacji rynkowej partnera. Nie można także wykluczyć postaw nieetycznych partnerów współpracy, np. przejęcia własności intelektualnej przez jednego z partnerów dla swoich wyłącznych korzyści. Co prawda, istnieją regulacje prawne, które mają przeciwdziałać takim praktykom, ale jednak z doświadczeń wielu przedsiębiorstw wynika, że takie nieetyczne zachowania zdarzają się w różnych krajach.

W badaniu działalności innowacyjnej przedsiębiorstw, zgodnie z Podręcznikiem Oslo [2006, s. 86], uwzględniane są następujące rodzaje instytucji partnerskich:

- inne przedsiębiorstwa należące do tej samej grupy przedsiębiorstw,

- dostawcy wyposażenia, materiałów, komponentów i oprogramowania,

- klienci,

- konkurenci i inne przedsiębiorstwa z tej samej dziedziny działalności,

- firmy konsultingowe (konsultanci), laboratoria komercyjne, prywatne instytucje $\mathrm{B}+\mathrm{R}$,

- placówki naukowe PAN,

- instytuty badawcze,

- zagraniczne publiczne instytucje $B+R$,

- szkoły wyższe.

W latach 2010-2012 w Unii Europejskiej (UE-27, brak danych dla Słowenii) w ramach działalności innowacyjnej w sektorze usług 14,9\% przedsiębiorstw aktywnych innowacyjnie współpracowało z innymi przedsiębiorstwami należącymi do tej samej grupy przedsiębiorstw, a 11,9\% przedsiębiorstw współpracowało z konkurentami reprezentującymi tę samą dziedzinę działalności (rys. 2). Największy odsetek firm współpracujących z innymi przedsiębiorstwami odnotowano w Wielkiej Brytanii (34,3\%), w Estonii (24,4\%), na Słowacji (24,2\%) oraz w Belgii (21,5\%). Z konkurentami w ramach działalności innowacyjnej najczęściej współpracowały przedsiębiorstwa w Wielkiej Brytanii $(22,2 \%)$ i Finlandii $(22,1 \%)$.

W sześciu krajach odnotowano większy odsetek firm współpracujących w zakresie działalności innowacyjnej z konkurentami niż z innymi przedsiębiorstwami (Cypr, Finlandia, Włochy, Węgry, Szwecja i Hiszpania). W Polsce współpraca w zakresie działalności innowacyjnej podejmowana jest przez przedsiębiorstwa z sektora usług w niewielkim zakresie. Zaledwie 11,4\% przedsiębiorstw aktywnych innowacyjnie podjęło współpracę z przedsiębiorstwami należącymi do tej samej grupy, a 6,5\% przedsiębiorstw współpracowało z konkurentami. Według K. Poznańskiej [2010, s. 173] w Polsce skłonność przedsiębiorstw do współpracy z instytucjami otoczenia jest stosunkowo niewielka, co wynika 
z braku zaufania między partnerami biznesowymi i dominacji źle pojmowanej kultury konkurencji. Prowadzi to do niedostrzegania we współpracy szans na wspólny rozwój czy poprawę indywidualnej pozycji konkurencyjnej.

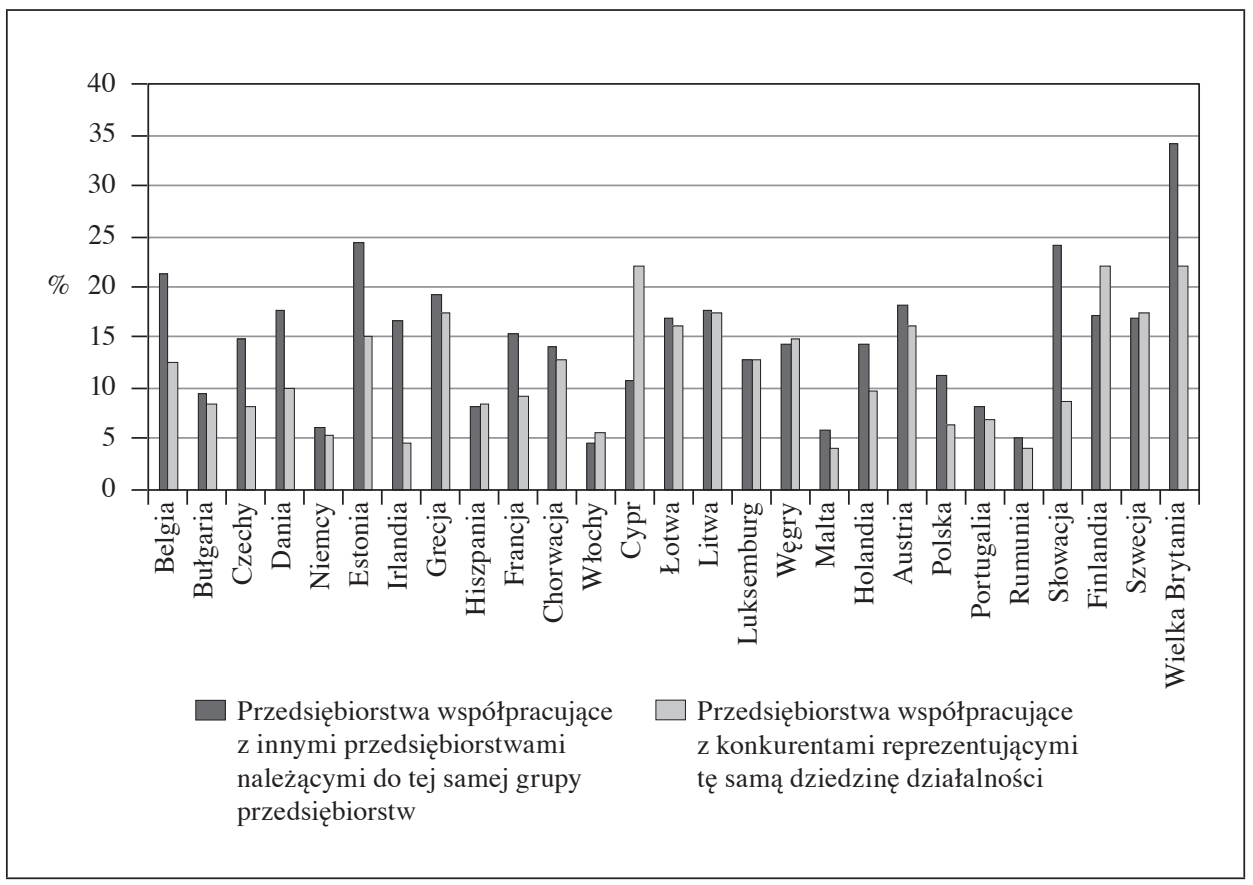

Rys. 2. Współpraca przedsiębiorstw z sektora usług w zakresie działalności innowacyjnej z innymi przedsiębiorstwami i z konkurentami w państwach Unii Europejskiej (UE-27) w latach 2010-2012 (\% przedsiębiorstw z sektora usług aktywnych innowacyjnie)

Źródło: http://appsso.eurostat.ec.europa.eu/nui/show.do?dataset=inn_cis8_coop\&lang=en (data dostępu: 12.08.2016).

Głównym partnerem we współpracy w zakresie działalności innowacyjnej w przedsiębiorstwach z sektora usług byli dostawcy wyposażenia, materiałów, komponentów i oprogramowania (tabela 1). Największy odsetek przedsiębiorstw usługowych współpracujących właśnie z tą grupą partnerów odnotowano na Cyprze (47,9\%), w Grecji $(38,7 \%)$ i Wielkiej Brytanii $(38,6 \%)$. Natomiast najniższym odsetkiem przedsiębiorstw korzystających z tej formy współpracy charakteryzowały się Niemcy (7,1\%), Malta (7,7\%) i Włochy 9,3\%). W Polsce odsetek firm usługowych współpracujących z dostawcami wyniósł 18,1\% ogółu przedsiębiorstw aktywnych innowacyjnie. 


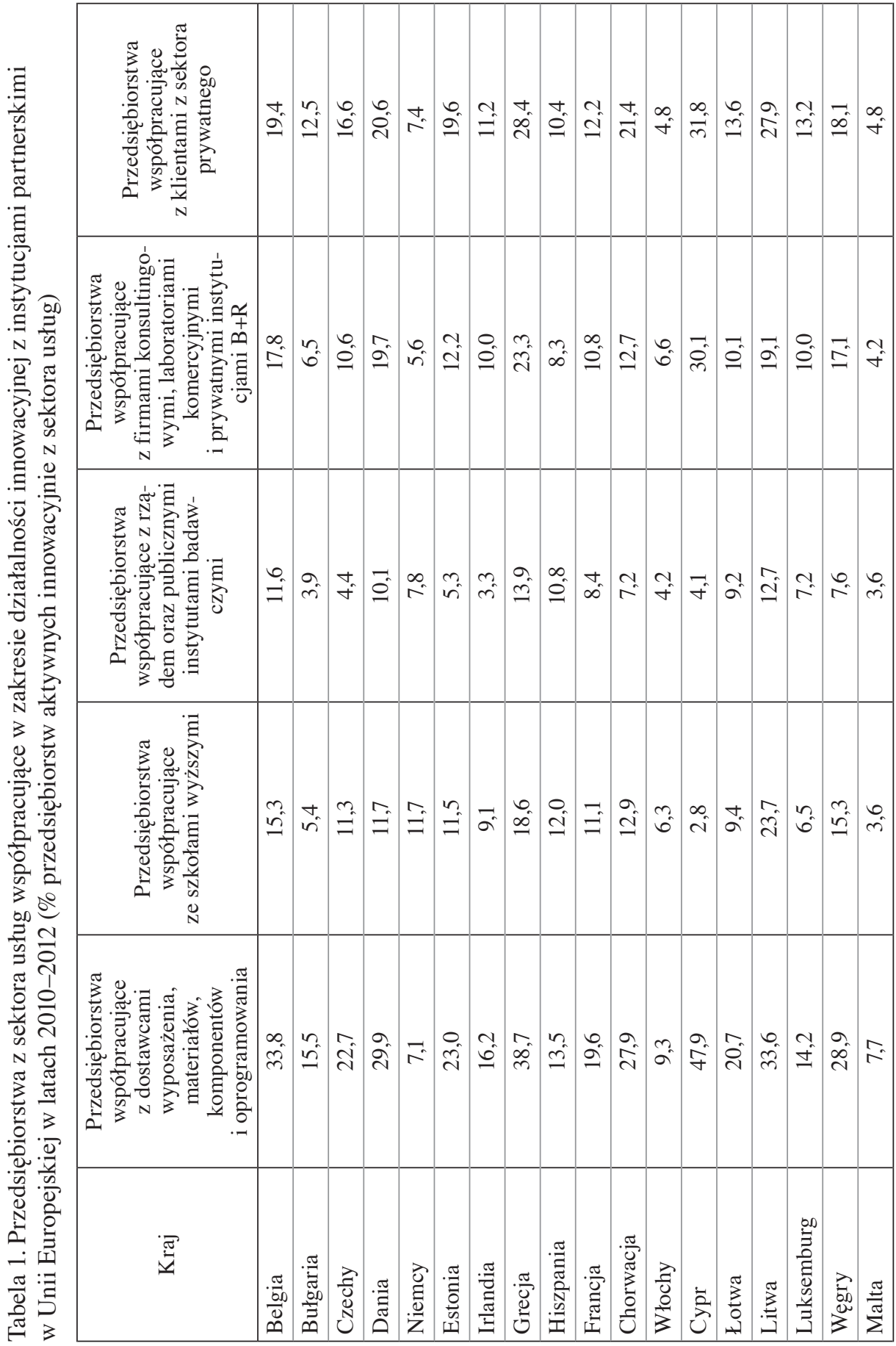




\begin{tabular}{|c|c|c|c|c|c|c|c|c|c|}
\hline 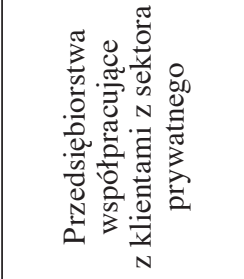 & $\begin{array}{l}\partial \\
\pm\end{array}$ & Oे. & $\begin{array}{l}\infty \\
\sigma\end{array}$ & $\begin{array}{l}\infty \\
\stackrel{0}{0}\end{array}$ & $\hat{\varrho}$ & $\begin{array}{l}\text { Nִ } \\
0\end{array}$ & $\hat{n}$ & $\overrightarrow{\tilde{\lambda}}$ & $\begin{array}{l}\infty \\
\dot{f}\end{array}$ \\
\hline 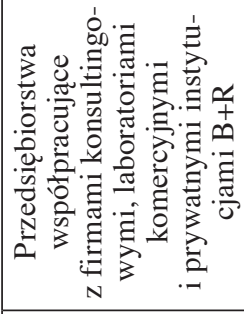 & $\begin{array}{l}\tilde{n} \\
0 \\
0\end{array}$ & 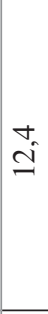 & $\stackrel{\infty}{\sim}$ & $\vec{\infty}$ & $\begin{array}{l}n \\
6\end{array}$ & $\begin{array}{l}\infty \\
\sigma\end{array}$ & $\underset{\Xi}{\stackrel{\Xi}{\Xi}}$ & $\begin{array}{l}\infty \\
0^{\circ}\end{array}$ & $\vec{\sim}$ \\
\hline 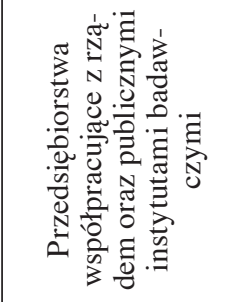 & $\begin{array}{l}2 \\
2\end{array}$ & $\cong$ & $\begin{array}{l}\tilde{y} \\
6\end{array}$ & $\stackrel{F}{\sim}$ & $\begin{array}{l}0 \\
\infty\end{array}$ & $\vec{f}$ & $\begin{array}{l}\infty \\
i n\end{array}$ & $\cdot$ & $\stackrel{+}{\varrho}$ \\
\hline 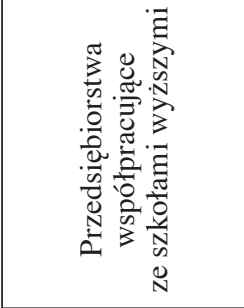 & $\sigma^{\prime}$ & ڤू & $m^{2}$ & $\begin{array}{l}\infty \\
\sigma\end{array}$ & $\vec{n}$ & $\begin{array}{l}\dot{\forall} \\
\stackrel{2}{ }\end{array}$ & $\begin{array}{c}0 \\
0 \\
0\end{array}$ & $\stackrel{?}{=}$ & $\begin{array}{l}\infty \\
\stackrel{\sim}{0}\end{array}$ \\
\hline 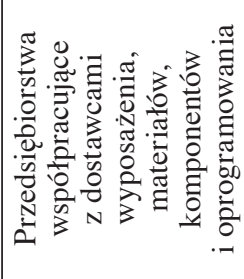 & $\begin{array}{l}\infty \\
\tilde{N} \\
\tilde{N}\end{array} \mid$ & $\begin{array}{l}\infty \\
\stackrel{+}{\sim}\end{array}$ & $\vec{\infty}$ & $\begin{array}{l}\infty \\
\pm \\
\pm\end{array}$ & $\stackrel{\partial}{=}$ & $\vec{n}$ & $\begin{array}{l}0 \\
\vec{d}\end{array}$ & $\hat{\mathrm{N}}$ & $\begin{array}{l}0 \\
\infty \\
\infty \\
\end{array}$ \\
\hline 芴 & 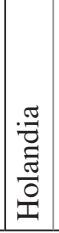 & 㸓 & $\begin{array}{l}\frac{\pi}{\tilde{y}} \\
\frac{a}{0} \\
0\end{array}$ & 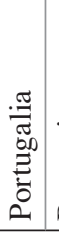 & 离 & $\begin{array}{l}\frac{\pi}{0} \\
\frac{\pi}{\pi} \\
\frac{3}{2} \\
\frac{\pi}{n}\end{array}$ & 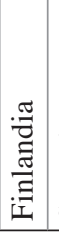 & $\begin{array}{l}\frac{\pi}{J} \\
\frac{0}{3} \\
\sqrt[3]{N}\end{array}$ & 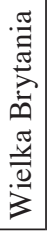 \\
\hline
\end{tabular}


Równie ważnym partnerem we współpracy w zakresie działalności innowacyjnej dla przedsiębiorstw usługowych są klienci (rynek). Często bezpośredni kontakt usługobiorcy z usługodawcą sprawia, że powstają zupełnie nowe usługi będące odpowiedzią na potrzeby klientów. Powstawanie innowacji w usługach opiera się na różnego rodzaju relacjach zachodzących zarówno wewnątrz przedsiębiorstwa, między poszczególnymi działami tego przedsiębiorstwa, jak i w kontaktach z otoczeniem - klientami. Należy jednak podkreślić, że źródła innowacji w usługach zależą od rodzaju usług i ich specyfiki. W usługach tradycyjnych (transport, handel) klienci odgrywają istotną rolę we wdrażaniu innowacji, natomiast $w$ usługach finansowych, ubezpieczeniowych czy telekomunikacyjnych zdecydowanie ważniejszym źródłem jest samo przedsiębiorstwo lub dostawcy wyposażenia i oprogramowania [Węgrzyn 2015, s. 90]. Najwyższym odsetkiem przedsiębiorstw usługowych współpracujących z klientami z sektora prywatnego w ramach działalności innowacyjnej charakteryzowały się: Wielka Brytania $(44,8 \%)$, Cypr $(31,8 \%)$, Grecja $(28,4 \%)$ i Litwa $(27,9 \%)$. Najniższym odsetkiem firm współpracujących z klientami charakteryzowały się natomiast: Malta $(4,8 \%)$, Włochy $(4,8 \%)$, Niemcy $(7,4 \%)$ i Polska $(9,8 \%)$.

Najwyższy odsetek przedsiębiorstw usługowych korzystających w ramach działalności innowacyjnej ze współpracy ze szkołami wyższymi odnotowano na Litwie (23,7\%), w Wielkiej Brytanii (20,8\%) i Finlandii (20,0\%). Najrzadziej ze szkołami wyższymi współpracowały przedsiębiorstwa usługowe na Cyprze $(2,8 \%)$, Malcie $(3,6 \%)$ i w Rumunii $(5,1 \%)$. Polska należy do krajów, w których współpraca ze szkołami wyższymi osiąga stosunkowo niski poziom. W latach 2010-2012 zaledwie 8,6\% przedsiębiorstw usługowych deklarowało współpracę ze szkołami wyższymi w ramach działalności innowacyjnej.

Kolejna grupa partnerów, z którymi przedsiębiorstwa usługowe współpracują w zakresie działalności innowacyjnej, to firmy konsultingowe, laboratoria komercyjne i prywatne instytucje B+R. Z tą grupą partnerów najczęściej współpracowały przedsiębiorstwa usługowe na Cyprze (30,1\%), w Wielkiej Brytanii $(24,1 \%)$ i w Grecji $(23,3 \%)$. Najniższy odsetek przedsiębiorstw korzystających z tego rodzaju współpracy odnotowały: Malta $(4,2 \%)$, Niemcy $(5,6 \%)$, Rumunia $(6,2 \%)$ i Włochy $(6,6 \%)$. W Polsce odsetek firm usługowych współpracujących z firmami konsultingowymi, laboratoriami komercyjnymi i prywatnymi instytucjami $\mathrm{B}+\mathrm{R}$ wyniósł 7,8\% ogółu aktywnych innowacyjnie przedsiębiorstw.

Ostatnią grupę partnerów współpracujących w ramach działalności innowacyjnej stanowią rząd i publiczne instytuty badawcze. $\mathrm{Z}$ tą grupą partnerów najczęściej współpracowały przedsiębiorstwa usługowe w Finlandii (15,8\%), Grecji $(13,9 \%)$, Wielkiej Brytanii $(13,4 \%)$ i na Litwie $(12,7 \%)$. Z kolei najniższy odsetek przedsiębiorstw korzystających z tego rodzaju współpracy odnotowano w Irlandii $(3,3 \%)$, na Malcie $(3,6 \%)$ i w Bułgarii $(3,9 \%)$. W Polsce w ramach działalności 
innowacyjnej z rządem i publicznymi instytutami badawczymi współpracowało 6,2\% ogółu przedsiębiorstw usługowych aktywnych innowacyjnie.

\section{Wnioski}

Ponieważ tworzenie innowacji to interaktywny proces współpracy w rosnącej i zróżnicowanej sieci interesariuszy, szczególnie ważna jest umiejętność współpracy z innymi podmiotami. Współpraca staje się środkiem do rozszerzenia zakresu projektów rozwojowych, sposobem na uzupełnienie kompetencji oraz podniesienie zdolności innowacyjnej firmy. Innowacyjny produkt czy usługa powstają jako wynik pracy interdyscyplinarnego, a jednocześnie interorganizacyjnego zespołu. Partnerami w takim przypadku są najczęściej dostawcy, partnerzy z innych branż lub rynków geograficznych, jak również sami klienci. Partnerami w tworzeniu innowacji są także firmy, które wykorzystują usługi lub produkty danej branży do tworzenia nowych zastosowań lub nowych rynków.

Z przeprowadzonej analizy wynika, że przedsiębiorstwa z sektora usług w krajach zaliczanych do liderów innowacyjności w znacznie większym stopniu współpracują w zakresie działalności innowacyjnej z instytucjami partnerskimi niż w krajach o niskiej czy umiarkowanej innowacyjności. Szczególnie ważna z punktu widzenia wzrostu poziomu innowacyjności gospodarki jest współpraca przedsiębiorstw z sektora usług z dostawcami sprzętu, materiałów, komponentów i oprogramowania (Dania, Holandia), z klientami z sektora prywatnego (Finlandia, Szwecja) oraz ze szkołami wyższymi (Niemcy). Współpraca w zakresie działalności innowacyjnej stanowi jeden z najbardziej istotnych obszarów szerzenia tego typu działalności. Ponadto współpraca skutkuje dużym potencjałem synergii, ponieważ partnerzy uczą się od siebie nawzajem.

\section{Literatura}

Cygler J. [2013], Charakterystyka kooperacji [w:] Kooperacja przedsiębiorstw w dobie globalizacji. Wyzwania strategiczne, uwarunkowania prawne, red. J. Cygler i in., Wolters Kluwer Business, Warszawa.

Działalność innowacyjna przedsiębiorstw w latach 2008-2010 [2012], Informacje i Opracowania Statystyczne, GUS, Warszawa.

Działalność innowacyjna przedsiębiorstw w latach 2012-2014 [2015], Informacje i Opracowania Statystyczne, GUS, Warszawa.

Ietto-Gillies G. [2002], Internationalization and the Demarcation between Services and Manufactures: A Theoretical and Empirical Analysis [w:] Internationalization, Technology and Services, red. M. Miozzo, I. Miles, Edward Elgar Publishing, Cheltenham. 
Innovation Union Scoreboard 2016 [2016], European Commission, http://ec.europa.eu/ DocsRoom/documents/17822 (data dostępu: 20.08.2016).

Neć M. [2013], Działalność innowacyjna przedsiębiorstw w Polsce na tle krajów Europy [w:] Świt innowacyjnego społeczeństwa. Trendy na najbliższe lata, red. P. Zadura-Lichota, PARP, Warszawa.

Podręcznik Oslo. Zasady gromadzenia i interpretacji danych dotyczqcych innowacji. Wydanie trzecie [2006], Komisja Europejska, Organizacja Współpracy Gospodarczej i Rozwoju, Urząd Statystyczny Wspólnot Europejskich, Warszawa.

Popławski W. [2009], Znaczenie i uwarunkowania wspótpracy z instytucjami naukowo-badawczymi w budowaniu potencjału innowacyjnego przedsiębiorstw [w:] Czynniki wzrostu konkurencyjności przedsiębiorstw i regionów, red. W. Karaszewski, M. Haffer, Wydawnictwo Naukowe Uniwersytetu Mikołaja Kopernika, Toruń.

Porter M.E. [1990], The Competitive Advantage of Nations, Macmillan, New York-London. Poznańska K. [2010], Wspótpraca przedsiębiorstw w teorii i polityce gospodarczej [w:] Kreatywność - innowacje - przedsiębiorczosśc, Zeszyty Naukowe Uniwersytetu Szczecińskiego, nr 579, Ekonomiczne Problemy Usług, nr 47, Szczecin.

Szymoniuk B., Walkiewicz S. [2001], Lokalne systemy produkcyjne jako stymulatory innowacyjności [w:] Wspólna Europa. Przedsiębiorstwo wobec globalizacji, red. J. Skalik, SGH, PWE, Warszawa.

Węgrzyn G. [2015], Innowacje w sektorze usług a zmiany strukturalne w zatrudnieniu, Wydawnictwo Uniwersytetu Ekonomicznego we Wrocławiu, Monografie i Opracowania, nr 256, Wrocław.

\section{Business Collaboration on Innovation, as Exemplified by the Service Sector (Abstract)}

The article identifies differences in enterprises' collaboration on innovation across the European Union. The first part explains the concept of innovative activity of business and examines the percentage of enterprises actively pursuing innovation in individual EU countries. The next part describes the methods of collaboration on innovation employed by enterprises in the service sector, by selected groups of partner institutions.

Service providers located in countries classified as innovation leaders have much closer collaboration on innovation with their partner institutions than those located in countries with low or moderate innovation levels. What seems particularly important for any economy's innovation level is the collaboration of service providers with the suppliers of equipment, materials, components and software (Denmark, the Netherlands), with their clients from the private sector (Finland, Sweden) and with universities (Germany).

Keywords: service sector, innovative activities, enterprise collaboration on innovation, innovation. 